of seaweeds will be further investigated, and a detriled report will be published elsewhere.

ARNE HAUG
BJørn LARSEN
Norwegian Institute of Serweed Research,
Trondheim. Feb. 19.

\section{Occurrence of D-Acylase in Soil Bacteria}

IN work reported earlier ${ }^{1}$, it was shown that a strain of Pseudomonas sp., KT83, can hydrolyse $\mathrm{N}$-benzoyl derivatives of both $\mathrm{L}$ - and $\mathrm{D}$-forms of amino-acids such as phenylalanine, tyrosine and alanine.

In a further experiment carried out with the KT83 acetone powder, it was found that the $\mathrm{N}$-dichloroscetylated $\mathrm{D}$-isomers of threo- $\beta$-phenyl serine, threo- $\beta$-p-nitrophenylserine and phenylglycine were hydrolysed more easily than the corresponding $\mathrm{N}$-dichloroacetylated L-isomers, suggesting the possible occurrence of D-acylase in this bacterial species. The present communication is concerned with evidence for the occurrence in Nature of $\mathrm{D}$-acylase, which hydrolysed only the $\mathrm{D}$-forms, but not the L-isomers of $\mathrm{N}$-acylated amino-acids.

$K T 83$ was grown in 1 litre of bouillon at $25^{\circ} \mathrm{C}$ for two days, and the cells were then harvested by centrifugation and washed with distilled water. The yield of cells, in wet weight, was approximately $14 \mathrm{gm}$. The cells, after having been ground with alumina, were extracted with $40 \mathrm{ml}$. of distilled water. Crude extract thus obtained was dialysed against cold distilled water for $15 \mathrm{hr}$. To $40 \mathrm{ml}$. of the dialysed crude extract was added $8 \mathrm{ml}$. of a 1 per cent solution of protamine sulphate, and the precipitate resulting was removed by centrifugation. To the clear supernatant fluid was added $24 \mathrm{ml}$. of a 1 per cent solution of protamine sulphate. The white precipitate, which contained most of the activity of $L$-acylase, was separated by centrifuging, and dissolved in $1.5 \mathrm{M}$ sodium chloride solution and dialysed first against 1.5 $M$ sodium chloride solution for $30 \mathrm{hr}$., and secondly against distilled water for $20 \mathrm{hr}$. (partially purified $L$-acylase sample).

At the same time, the clear, straw-coloured supernatant, which contained most of the activity of D-acylase, was fractionated by addition of increasing amounts of saturated ammonium sulphate. The fraction which was precipitated between 50 and 60 per cent saturation of ammonium sulphate and which would be most active was dialysed against distilled water for $10 \mathrm{hr}$. until free of ammonium sulphate. The inside fluid was then centrifuged to remove inactive protein which was precipitated during the dialysis (partially purified D-acylase sample).

The enzymatic assay was performed according to Grassmann and Heyde's method. Protein was

Table 1

\begin{tabular}{|c|c|c|c|c|}
\hline \multirow{3}{*}{$\begin{array}{l}\text { Enzyme } \\
\text { sample }\end{array}$} & \multirow{2}{*}{\multicolumn{2}{|c|}{$\frac{\text { Specific activity }}{\text { Benzoyl-phenylalanine }}$}} & \multirow{2}{*}{\multicolumn{2}{|c|}{$\frac{\text { Total activity }}{\text { Benzoyl-phenylalanine }}$}} \\
\hline & & & & \\
\hline & D- & L- & D- & L- \\
\hline \multirow{3}{*}{$\begin{array}{l}\text { Crude extract } \\
\text { Partially puri } \\
\text { fled L-acylase } \\
\text { Partially puri- } \\
\text { fied D-acylase }\end{array}$} & $2 \cdot 3$ & $11 \cdot 5$ & 1,035 & 5,175 \\
\hline & $1 \cdot 0$ & $23 \cdot 0$ & 120 & 2,760 \\
\hline & $32 \cdot 0$ & $<0.03$ & 520 & $<0.5$ \\
\hline
\end{tabular}
Expressed as micromoles hydrolysed per hr. per mgm. protein.
The digests consisted of $0.5 \mathrm{ml}$. enzyme solution, $0.5 \mathrm{ml}$. of water and $1 \mathrm{ml}$. of $0.05 \mathrm{M}$ neutralized substrate $(p H 8)$ at $37^{\circ} \mathrm{C}$. determined by the phenol method of Lowry et al. The acylase-activities of crude extract, partially puri. fied L-acylase and partially purified D-acylase, are shown in Table 1.

On the other hand, the resolution experiment, in which $6 \mathrm{ml}$. (15 mgm. of protein) of the partially purified D-acylase sample was made to act on $1.35 \mathrm{gm}$. of benzoyl-DL-phenylalanine at $37^{\circ} \mathrm{C}$. for $20 \mathrm{hr}$. !gave the following results: $0.33 \mathrm{gm}$. (80 per cent) of D-phenylalanine $[\alpha]_{D}^{15}=+35 \cdot 0^{\circ}\left(c=2, \mathrm{H}_{2} \mathrm{O}\right)$; 0.57 gm. (84 per cent) of benzoyl-L-phenylalanine $[\alpha]_{D}^{15}=+14.9^{\circ} \quad(c=3, \quad N N a O H)$ m.p. $139-40^{\circ}$; $0.25 \mathrm{gm}$. (82 per cent) of benzoic acid m.p. 118-20.

YUKTO KAMEDA

ETSUKO TOYOURA

YUKIO KIMURA

Laboratory of Antibiotics,

Faculty of Pharmacy,

Kanazawa University, Japan. Feb. 21.

${ }^{1}$ Kameda, Y., Toyoura, E., Yamazoe, H., Kimura, Y., and Yasuda Y., Nature, 170, 888 (1952).

${ }^{2}$ Kameda, Y. Toyoura, E., Kimura, Y., and Matsui, K., Yakugaku Zasshi, 78, 202 (1958).

\section{Colonization of Anopheles funestus}

Attempts to colonize A. funestus funestus Giles, the second most important vector of malaria in Africa, commenced in 1954 and continued for three years. During 1955-56 the first successful colony of this mosquito was established from eggs laid by wild-caught females of $A$. funestus, given alternative feeds on human and guinea pig blood. The egg production of this colony was of short duration and small quantity, and the colony eventually died out after a few months.

In August 1957 another colony was established from wild-caught, gravid females maintained on guines pig blood meals only. This colony, now in its eighth generation, is remarkable for its vigour and egg production. The eggs are laid on filter paper immersed in a dish filled with water; the larvæ are maintained in bowls filled with tap water with floating water weed Elodea canadensis. Larval food consists of pure dried yeast. Adults are kept in cages 1 cu.ft. capacity in total darkness ; anæsthetized guinea pigs are used daily as a source of blood meals for female mosquitoes; males are fed on sugar solution freely available in the cage. The duration of the cycle from eggs to pupæ is about 21 days at the temperature $80-85^{\circ} \mathrm{F}$. Two egg batches of this colony were sent by air to London where a subsidiary colony was successfully established. Studies on the taxonomy and bionomics of this colony are now in progress.

M. W. SERvice

Federal Malaria Service,

D. Oguamah

Yaba, Lagos, Nigeria.

Feb. 20.

\section{The General Relationship between Test Factors and Person Factors ; Application to Preference Matrices}

THE application of factor analysis to correlations between persons had already become widespread among psychologists when it was made the subject of a special study by Burt and Stephenson shortly before the Second World War. They began in collaboration, but concluded by differing ${ }^{1}$ in their 